\title{
THE EFFECT OF HUMAN SERUM ALBUMIN, MERCURIAL DIURETICS, AND A LOW SODIUM DIET ON SODIUM EXCRETION IN PATIENTS WITH CIRRHOSIS OF THE LIVER ${ }^{1,2,3}$
}

\author{
By WILLIAM W. FALOON,^ RICHARD D. ECKHARDT, 5 ARNOLD M. COOPER, \\ AND CHARLES S. DAVIDSON \\ (From the Thorndike Memorial Laboratory, Second and Fourth Medical Services [Harvard],
Boston City Hospital, and the Department of Medicine, Harvard Medical School, Boston)
}

(Received for publication August 30, 1948)

The relative importance of the serum albumin concentration, portal hypertension, and antidiuretic substances in the formation of ascites and edema in patients with cirrhosis of the liver has not been clarified. There is evidence, however, that each of these factors is important (1-3).

In an effort to eliminate the factor of hypoalbuminemia, salt-poor concentrated human serum albumin has been given intravenously. Although the serum albumin concentration may by this means be raised to normal, the edema and ascites have not been consistently relieved (4-7): Moreover, improvement in ascites and edema is observed in some instances with mercurial diuretics or simply by furnishing a nutritious diet alone $(8,9)$. In an attempt to find an abnormality common to these patients and consistently altered by the apparently unrelated therapeutic agents, the studies of sodium excretion and balance reported here were undertaken.

\section{METHODS}

The 11 patients studied had ascites and edema associated with cirrhosis of the liver, established by history,

1 A preliminary report of this investigation was presented before the national meeting of the American Federation for.Clinical Research, Atlantic City, N. J., May 4, 1948 (Am. J. Med., 1948, 5, 623).

2 The serum albumin used in this study was processed by the American National Red Cross from blood which it collected from voluntary donors. This is one of a series of investigations on serum albumin being carried out with material supplied by the American National Red Cross. As soon as sufficient data become available to justify final conclusions concerning its therapeutic value a full report to the medical profession on the use of serum albumin in medical practice will be published.

3 This study was aided in part by a gift to Harvard University from the Abbott Laboratories, North Chicago, Illinois.

4 Present address: Albany Hospital, Albany 1, New York.

SU. S. Public Health Service Postdoctorate Research Fellow. physical examination, liver function tests, and occasionally by needle biopsy. Six patients had had a previous trial with intravenous albumin when the diet was unrestricted in sodium without marked response (patients V. L., W. M., C. M., H. H., A. McM., and J. McC.). The others were observed for two or more weeks on an unrestricted diet and no tendency for spontaneous improvement had been shown at the time studies were begun. None of the patients showed evidence of co-existing cardiac or renal disease.

With the exception of experiment No. II (S. P.), a low sodium diet was used. To increase the protein and caloric content of the diet, 150 grams of salt-poor milk powder containing 45 grams of protein mixed with water were used in place of milk. ${ }^{6}$ By calculation, ${ }^{7}$ the diet contained 100 grams of protein, 3,000 calories, and only $21 \mathrm{mEq}$. (0.5 grams) of sodium daily, and was well tolerated by the subjects. The sodium contained in the albumin solution ${ }^{8}$ was added to the sodium intake. $\mathrm{Pa}$ tients who received added sodium were given weighed amounts of salt and were either instructed to use it daily on their food or it was mixed in food and fluids consumed.

All patients were carefully followed on the Thorndike metabolic ward, with nurses and a dietitian in constant attendance. Strict control of each patient's dietary intake and urinary output was maintained throughout the study. All patients were allowed to drink water freely, and the daily fluid (liquid) intake was recorded. Fluid balance measurements obtained by differences between the fluid intake (liquids plus estimated fluid ingested in the diet) and fluid output (urine plus estimated fluid lost via the

6 "Lonalac," supplied by Mead Johnson and Company, Evansville, Indiana. Each 150 grams of powder contains approximately $0.7 \mathrm{mEq}$. (15 mgm.) of sodium.

7 It has been pointed out (10) that diets analyzed for sodium usually contain more than the amount calculated. This, in addition to the fact that strict control over the use of canned foods was not always possible, constitutes probable sources of error in our calculation of sodium balances. As will be seen, however, these factors merely accentuate the retention of sodium shown in these patients. Thus, when sodium equilibrium is shown, there is probably in reality a slight positive sodium balance.

8 The sodium contents of the lots of albumin used were obtained through the courtesy of Dr. Charles A. Janeway, Children's Hospital, Boston. Each 25 grams of albumin contains approximately $15 \mathrm{mEq}$. (0.3 gram) of sodium. 
stools, lungs, and skin) are variable and unreliable. Since all patients in this study were weighed daily under similar conditions, it was considered that changes in body weight reflected more accurately changes in fluid retention in the body than did the difference between the fluid intake and the urine output.

Urine sodium excretion was determined daily except for a few studies in which the urine was analyzed in three- or four-day pools. The method of Consolazio and Dill was used (11). The extrarenal sodium loss was estimated to be constant at $20 \mathrm{mEq}$. per day (12-14). The studies were carried out during the winter months so that perspiration was minimal.

Concentrated salt-poor human serum albumin (25 per cent solution) was given in amounts of from 25 to 75 grams $(100-300 \mathrm{cc}$.) in each injection with equal volumes of 5 or 10 per cent dextrose in distilled water. When maintenance of the serum albumin concentration was desired, 25 grams of albumin were administered daily, or three times weekly. The serum albumin concentration was determined by micro-Kjeldahl analysis of fractions separated by the method of Howe (15).

\section{RESULTS}

I. The effect on ascites and edema of varying the salt intake while maintaining a normal serum albumin concentration (Table I, Figures 1-5)

Four patients (W. M., C. M., H. H., and V. L.) who had previously had numerous abdominal

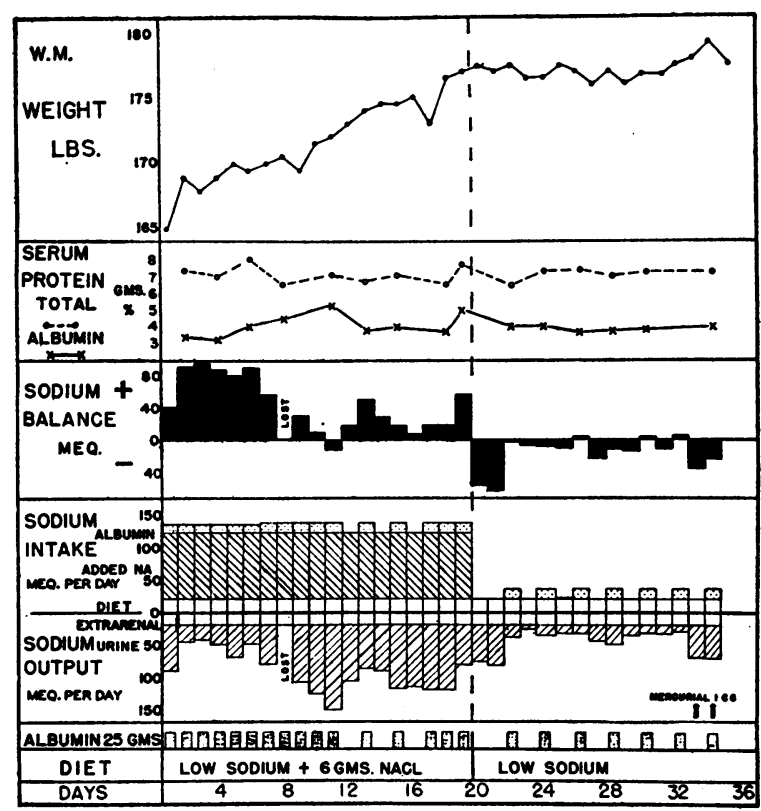

FIG. 1

paracenteses with regular reaccumulation of fluid, the "stabilized cirrhosis" of Patek (16), were maintained on the low sodium diet $(21 \mathrm{mEq}$. daily). They were then given sufficient albumin

TABLE I

Sodium excretion following intravenous saline

Low sodium ( $21 \mathrm{mEq}$.) diet throughout all studies. Serum albumin concentrations maintained within normal limits.

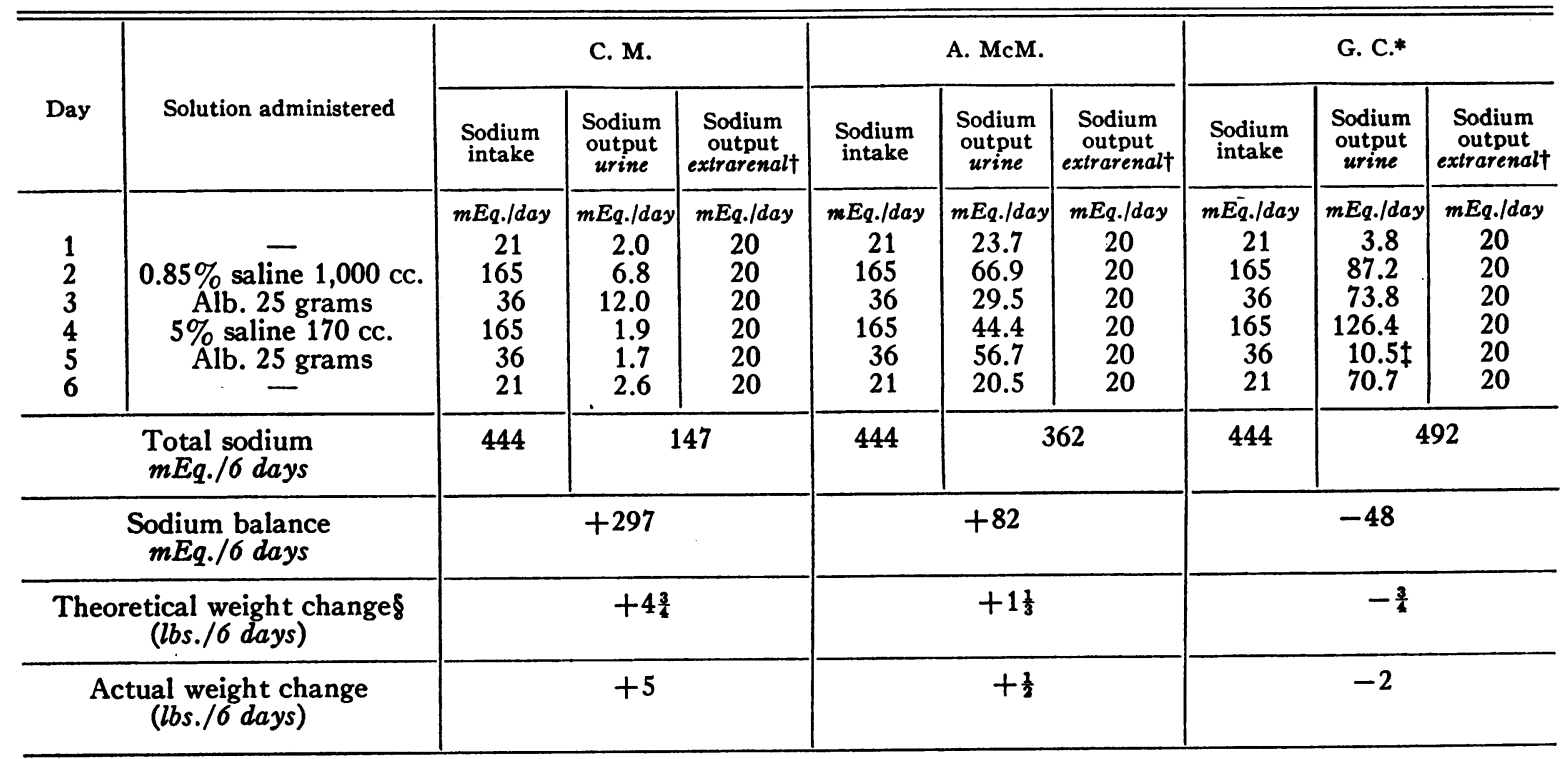

* Patient undergoing diuresis following albumin therapy.

tEstimated.

I Incomplete collection.

Calculated from the sodium bạlance, each $140 \mathrm{mEq}$. Na estimated to represent 1 liter of water (1 Kgm. or $2,2 \mathrm{lbs}$, ) 
intravenously to raise their serum albumin concentrations to above 3.2 grams per $100 \mathrm{cc}$. This, or a higher concentration, was maintained throughout the period of study. After a suitable control period on the low sodium intake, each patient was given daily 6 grams of salt (102 mEq. of sodium). Changes in sodium balance and weight in three of the patients are shown in Figures 1-3. Weight changes reflecting the probable alterations in sodium balance on the fourth subject are shown in Figure 4. In all four patients there was a similar

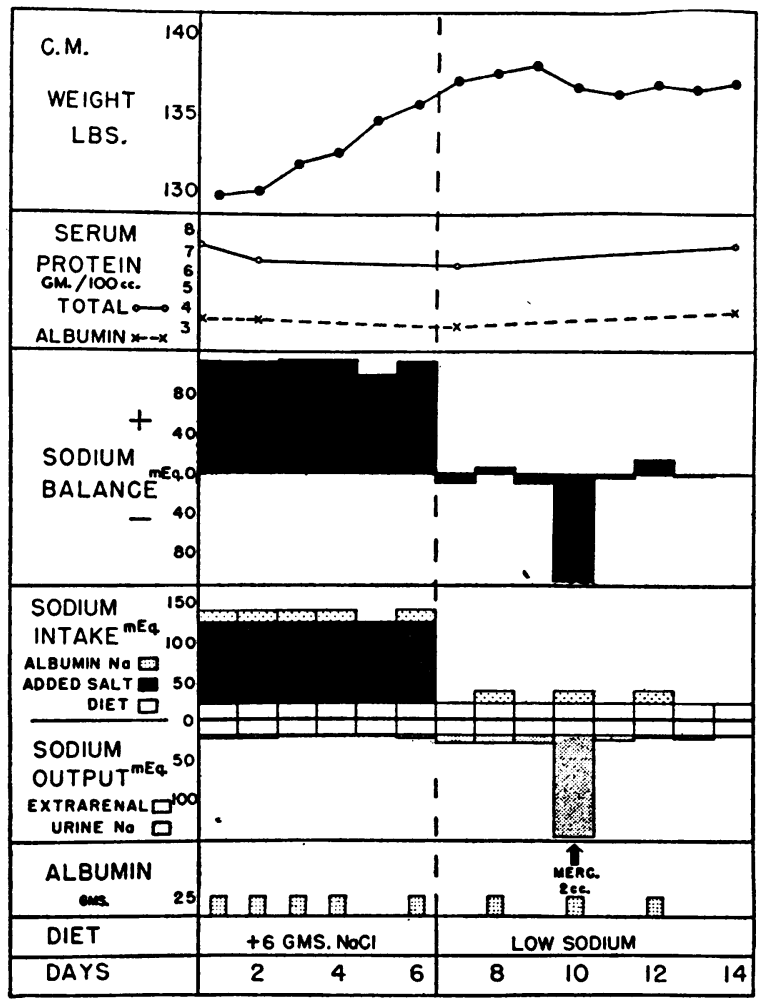

FIG. 2

increase in weight and ascites formation coincident with the administration of added salt. During this period the excretion of sodium in the urine of two patients (C. M. and H. H.) was no greater than during the period of low sodium intake, and was only moderately increased in the third patient (W. M.). As a result, all patients were in a markedly positive sodium balance while receiving supplemental sodium salts. Thus, a normal serum albumin concentration does not alone permit the excretion of excess sodium given orally.

It seemed possible that patients with cirrhosis

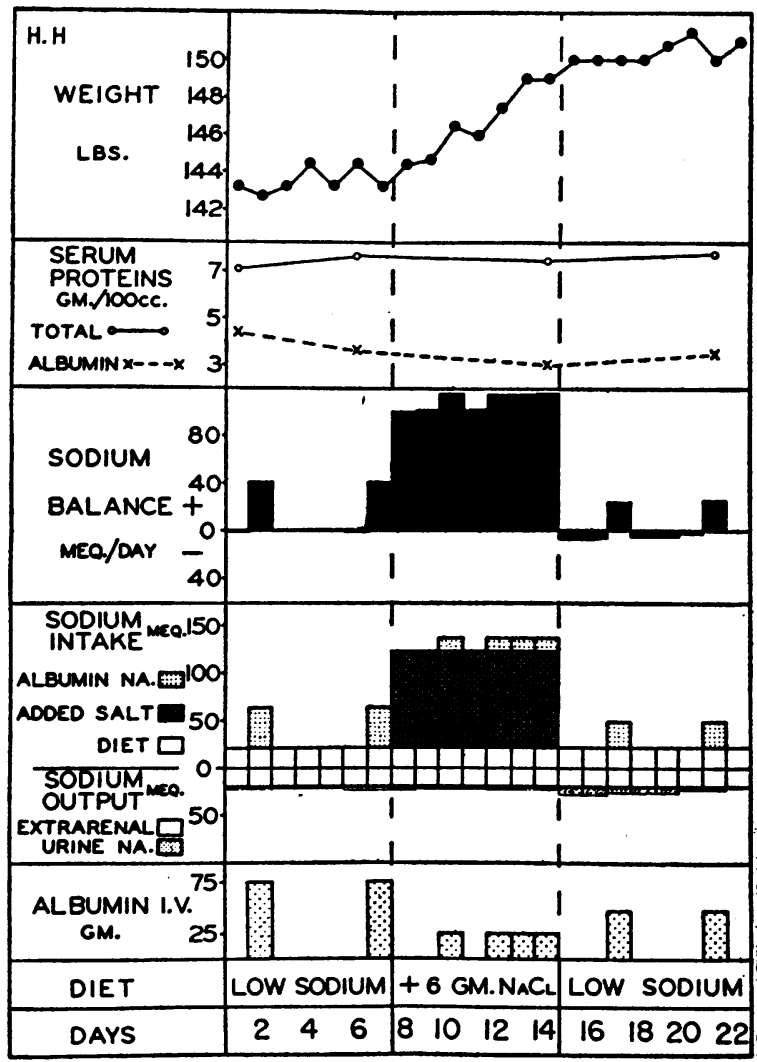

FIG. 3

of the liver might react differently to sodium administered intravenously. To study this, two patients, maintained on a low sodium diet, were given sufficient albumin to attain normal serum albumin concentrations and were then given saline intravenously in varying concentrations (C. M. and A. McM., Table I and Figure 5). After a control day, $1,000 \mathrm{cc}$. of isotonic saline was given intra-

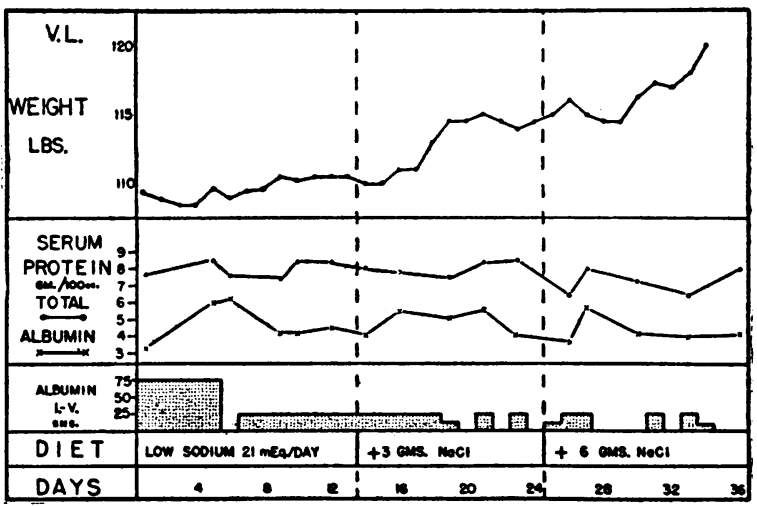

FIG. 4 


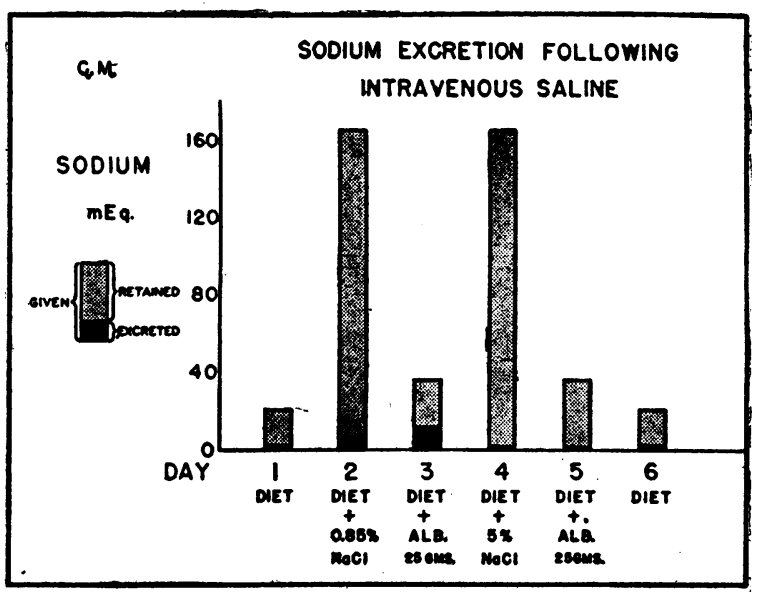

Fig. 5

venously. The following day, 25 grams of albumin were given and on the fourth day $170 \mathrm{cc}$. of hypertonic ( 5 per cent) saline. On the fifth day the albumin was repeated. A marked inability to excrete sodium was noted in both patients following the intravenous administration of isotonic and hypertonic saline. Moreover, diuresis did not occur following the saline administration. ${ }^{\circ}$ Although patient A. McM. was able to excrete sodium in a more nearly normal manner than C. M., neither subject was able to excrete sodium in high concentrations. Thus, the degree of sodium excretion varies with individual patients. These findings may be contrasted with those of a similar study on a patient with cirrhosis undergoing diuresis after serum albumin therapy (G. C., Table I). The latter was able to achieve sodium equilibrium.

\section{The effect of albumin administration on the excretion of sodium (Table II, Figure 6)}

Prompt diuresis with rapid loss of both edema and ascites is seen in a few patients with cirrhosis of the liver following the intravenous administra-

The administration of hypertonic salt solution intra-
venously in normal individuals stimulates the release of
an antidiuretic substance from the pituitary and dimin-
ishes urine flow for short periods of time (17). How-
ever, the administration of saline in hypo-, iso-, or hyper-
tonic concentrations in normally hydrated individuals,
allowed free access of water, results in a considerably
increased excretion of water if the urine collections are
made over longer periods of time, as in the present study (18). tion of albumin (7). One such patient (S. P., Figure 6) with marked ascites and massive edema of the lower extremities, scrotum and penis, was selected for study of sodium excretion. He was maintained on a diet calculated to contain 91 $\mathrm{mEq}$. of sodium daily. During the six days prior to the administration of albumin his urinary excretion of sodium averaged only $5 \mathrm{mEq}$. daily. On the second day of albumin administration (75 grams daily for six days) his urinary sodium excretion rose to $236 \mathrm{mEq}$. and thereafter averaged $156 \mathrm{mEq}$. daily. Weight loss began on the first day of albumin administration, and diuresis was sustained until he became free of ascites and edema after 25 days.

Such dramatic results following albumin administration are seen in only a few patients. More commonly, a temporary diuresis and loss of weight follow, or merely a decrease in the rate of weight gain may be observed. A patient (C. M., Table II) whose response fell into the latter category was provided with the low sodium diet to which, after a short control period, 6 grams of salt (102 mEq. of sodium) were added. With this high salt regimen he gained weight rapidly and sodium excretion remained at the control value of about $4 \mathrm{mEq}$. daily, so that he was in a marked positive sodium balance. Beginning on the sixth day he was given 50 grams of albumin daily for six days and 25 grams daily thereafter. Urinary sodium rose to $21 \mathrm{mEq}$. daily in the 12 th to 14 th day pool and subsequently to $40 \mathrm{mEq}$. daily in the next three-day pool as the serum albumin concentration further increased. However, sodium equilibrium was not achieved, and ascitic fluid accumulation continued. In spite of omitting the added salt for five days, with apparent negative sodium

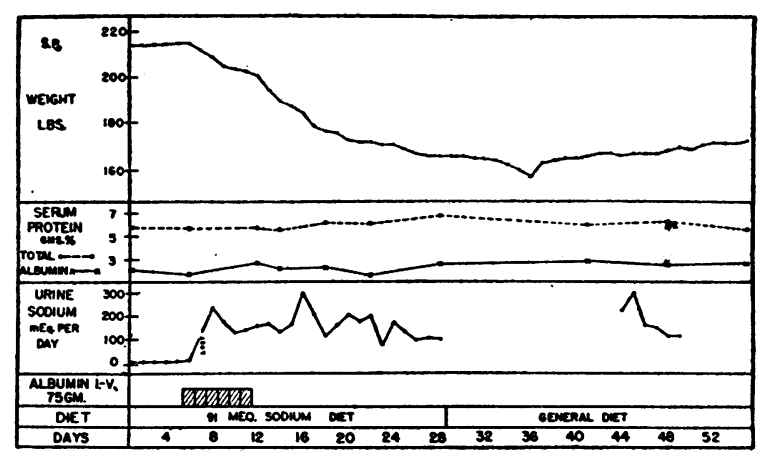

FIG. 6 
TABLE II

Sodium excretion following intravenous albumin

\begin{tabular}{|c|c|c|c|c|c|c|}
\hline \multirow{2}{*}{ Day } & \multicolumn{2}{|c|}{123 mEq. sodium diet } & \multicolumn{2}{|c|}{123 mE. Mc. sodium diet } & \multicolumn{2}{|c|}{$\underset{21}{\text { HEQ. Sodium diet }}$} \\
\hline & $\underset{\text { istered }}{\text { Albumin admin- }}$ & Urine sodium & $\underset{\text { istered* }}{\text { Albumin admin- }}$ & Urine sodium & $\underset{\text { istered }}{\text { Albumin }}$ & Urine sodium \\
\hline $\begin{array}{r}1 \\
2 \\
3 \\
4 \\
5 \\
6 \\
7 \\
8 \\
9 \\
10 \\
11 \\
12 \\
13 \\
14 \\
15 \\
16 \\
17\end{array}$ & $\begin{array}{l} \\
50 \\
50 \\
50 \\
50 \\
50 \\
50 \\
25 \\
25 \\
25 \\
25 \\
25\end{array}$ & $\begin{array}{c}m E q . / d a y \\
4.3 \\
4.0 \\
5.1 \\
7.5 \\
2.5 \\
4.3 \\
- \\
- \\
4.9 \\
5.3 \\
3.2 \\
21.0 \\
21.0 \\
21.0 \\
40.5 \\
40.5 \\
40.5\end{array}$ & $\begin{array}{c}\text { grams } \\
\\
\\
50 \\
50 \\
50 \\
50 \\
50 \\
50 \\
50 \\
72 \\
25\end{array}$ & $\begin{array}{c}m E q . / d a y \\
2.7 \\
6.0 \\
18.0 \\
19.4 \\
17.5 \\
35.5 \\
31.4 \\
42.9 \\
93.4 \\
64.6 \\
64.6 \\
64.6 \\
59.0 \\
59.0\end{array}$ & $\begin{array}{c}\text { grams } \\
\\
75 \\
75 \\
75 \\
\text { Paracentesis } \\
75 \\
75 \\
75 \\
75 \\
75 \\
75\end{array}$ & $\begin{array}{c}m E q . / \text { day } \\
1.0 \\
1.3 \\
1.8 \\
4.2 \\
1.1 \\
3.3 \\
4.5 \\
6.2 \\
7.7 \\
9.5 \\
3.0 \\
3.0\end{array}$ \\
\hline
\end{tabular}

* The administration of each 25 grams of albumin entails the giving of approximately $15 \mathrm{mEq}$. of sodium in addition to that in the diet.

balance during this period, a paracentesis became necessary.

Another patient (J. McC., Table II) with recurrent ascites and edema was similarly studied before and during the period of albumin administration. In the control period before albumin administration he was maintained on the low sodium diet during which time urinary sodium averaged $4 \mathrm{mEq}$. per day. Six grams of salt $(102 \mathrm{mEq}$. sodium) was then added to the diet and the urinary sodium rose in the subsequent five days to an average of $13 \mathrm{mEq}$. daily with a maximum of $19 \mathrm{mEq}$. on the fourth day. In the next period 50 grams of albumin were given daily, intravenously. In this period there was an increase in urinary sodium to $35 \mathrm{mEq}$. on the first day and an average excretion of $57 \mathrm{mEq}$. per day for the nine days of albumin administration. The increased sodium excretion was followed by a slow diuresis.

A similar study was conducted with patient $\mathrm{H}$. H. (Table II) who also had recurrent ascites. In his case, the low sodium diet was continued throughout without a period of added salt. After a control period of two days, albumin ( 75 grams daily) was administered, intravenously, for two days and on the third day ascitic fluid was removed by paracentesis. Albumin administration was then resumed for six more days. During the two-day control period, urinary sodium was 1.0 and 1.3 $\mathrm{mEq}$. daily, rising, after paracentesis, so that on the eighth day of albumin administration it was $9.5 \mathrm{mEq}$. Positive sodium balance and weight gain occurred during this period in spite of the increase in urinary sodium, since the administration of each 25 grams of albumin entails giving approximately $15 \mathrm{mEq}$. of sodium.

Data on the three patients shown in Table II demonstrate a considerable variability between patients in the increase of sodium excretion after albumin administration. A negative sodium balance was not achieved in these three patients in spite of albumin administration and the subsequent rise to normal of the serum albumin concentration.

\section{The effect of mercurial diuretics on sodium excretion (Table III)}

The rate of disappearance of ascites and edema following mercurial diuretics is often as rapid as after albumin administration. To compare the effect of mercurial diuretics on sodium excretion with the effect of albumin, two patients were studied. The first (J.Q.) had massive ascites and edema and a low serum albumin concentration. After a control period on a low sodium diet, he 
TABLE III

Sodium excretion following intravenous mercurials Low sodium diet-(21 mEq.)

\begin{tabular}{|c|c|c|c|c|c|c|}
\hline \multicolumn{3}{|c|}{ (serum albumin $\mathrm{J}_{\text {. }}^{\mathrm{Q}}$. grams \%) } & \multirow{2}{*}{ Day } & \multicolumn{3}{|c|}{$\underset{\text { (serum albumin } 2.4 \text { grams \%) }}{\text { C. M. }}$} \\
\hline $\begin{array}{l}\text { Urine } \\
\text { sodium }\end{array}$ & $\underset{\text { rial* }}{\text { Mercu- }}$ & Weight & & $\begin{array}{c}\text { Urine } \\
\text { sodium }\end{array}$ & $\underset{\text { rial* }}{\text { Mercu- }}$ & Weight \\
\hline $\begin{array}{c}m E q . / \text { day } \\
11.6 \\
7.4 \\
10.2 \\
48.1 \\
159.3 \\
191.5 \\
132.3 \\
124.5 \\
234.5 \\
138.3\end{array}$ & $\begin{array}{l}\mathrm{X} \\
\mathrm{X} \\
\mathrm{X} \\
\mathrm{X} \\
\mathrm{X}\end{array}$ & $\begin{array}{c}\text { lbs. } \\
214 \frac{3}{4} \\
214 \frac{3}{4} \\
215 \frac{3}{4} \\
214 \frac{1}{4} \\
213 \frac{1}{2} \\
216 \\
212 \frac{1}{\frac{3}{2}} \\
211 \frac{3}{4} \\
204 \frac{1}{2} \\
201 \frac{3}{4}\end{array}$ & $\begin{array}{r}1 \\
2 \\
3 \\
4 \\
5 \\
6 \\
7 \\
8 \\
9 \\
10\end{array}$ & $\begin{array}{c}m E q . / d a y \\
1.1 \\
6.6 \\
1.3 \\
62.0 \\
2.0 \\
39.0 \\
6.3 \\
25.2 \\
2.7 \\
30.2\end{array}$ & $\begin{array}{l}X \\
X \\
X\end{array}$ & $\begin{array}{l}l b s . \\
146 \frac{1}{2} \\
147 \\
147 \frac{3}{4} \\
148 \\
149 \\
148 \\
147 \frac{3}{4} \\
148 \\
148 \\
149 \frac{1}{2}\end{array}$ \\
\hline
\end{tabular}
(X).

*2 cc. "Mercuzanthin" intravenously as indicated

was given 2 cc. of a mercurial diuretic, ${ }^{10}$ intravenously daily for five days (Table III). Urinary sodium excretion averaged $9 \mathrm{mEq}$. daily during the control period, rose to $48 \mathrm{mEq}$. on the first day of diuretic therapy, and thereafter averaged over $130 \mathrm{mEq}$. for 12 days. During this period he lost $20 \mathrm{lbs}$. of weight, and subsequently became free of ascites and edema.

A second patient (C. M.) with chronic, recurrent ascites, and whose serum albumin concentration was low, was given a low sodium diet. Mercurial diuretics were given every other day for eight days, and daily urinary sodium determined (Table III). On the days of mercurial administration, sodium excretion varied between 25 and $62 \mathrm{mEq}$., while on control days, both between mercurial injections and after they had been discontinued, urinary sodium never exceeded 10 $\mathrm{mEq}$. The patient's weight changed little, however, and the marked diuresis seen in the first study did not occur.

Data on the patients shown in Table III demonstrate that the effect of mercurial diuretics varies in different patients and is possibly related to the relative severity of the liver disease.

\section{Sodium balance in a patient recovering from ascites (Figure 7)}

In one patient (W. M.) whose tendency to reform ascites appeared to be overcome, studies were

10 "Mercuzanthin," Campbell Products, Inc., New York, N. Y. made of his ability to excrete sodium during the recovery phase. Following a two-month interval, during which he was given maintenance albumin and a general diet unrestricted in sodium, and had had one paracentesis, W. M. was restudied (Figure 7). At this time he was given the low sodium diet and mercurial injections with slight weight loss. On being given the 6 grams of added salt he was able to excrete over $100 \mathrm{mEq}$. of sodium daily in his urine, sufficient to achieve sodium equilibrium. Very slight weight gain in the first four

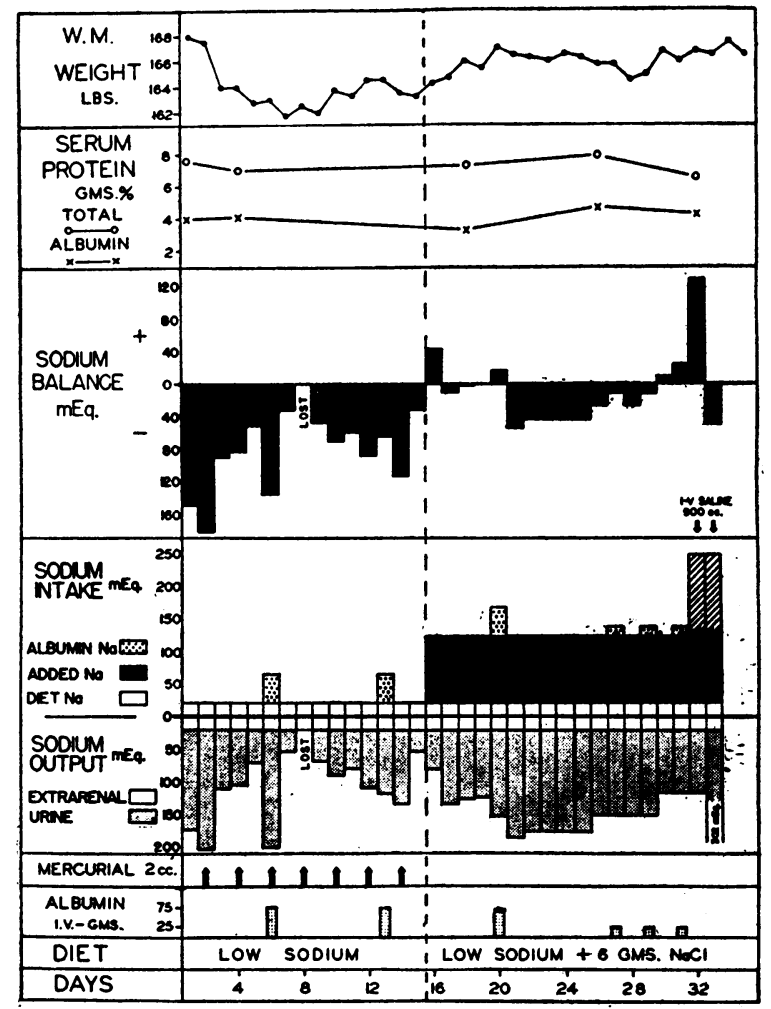

FIG. 7

days was recorded, and thereafter in spite of the added salt and further increments to his sodium intake by the administration of $900 \mathrm{cc}$. of normal saline intravenously daily for two days, weight remained constant. This patient had ceased to form ascites and, in spite of a high sodium intake, was able to excrete it apparently normally. It was previously observed that patient G. C. (Table I), while undergoing diuresis after serum albumin therapy, was likewise able quantitatively to excrete administered sodium. 


\section{DISCUSSION}

The patients with cirrhosis of the liver and with demonstrable fluid retention reported here excreted in the urine but small quantities of orally or intravenously administered sodium. Positive sodium balance thus inevitably occurred. Sodium excretion increased, occasionally to permit negative sodium balance, in three circumstances : during a spontaneous decrease in ascites and edema formation; following the intravenous administration of albumin; and accompanying the parenteral exhibition of mercurial diuretics. The influence of these circumstances on fluid retention varied greatly from patient to patient. Thus, following intravenous albumin administration one patient who had never required paracentesis had a massive and prolonged diuresis with a marked increase in urinary sodium excretion. In other patients with ascites requiring repeated paracenteses the increased sodium excretion, although evident, was transitory and not great enough to lead to negative sodium balance. Likewise, the effect of mercurial diuretics on sodium excretion and diuresis was variable; one patient achieved a slow but prolonged diuresis with a considerable increase in urinary sodium excretion, while in another the effect was only transitory.

The rate of ascites formation could be altered by changing the quantity of sodium administered to patients with chronic cirrhosis in whom repeated paracenteses were necessary. Thus, a decrease in sodium intake slowed the rate of ascites formation and, conversely, fluid retention increased as more sodium was administered. This relationship held true despite the maintenance in some instances of a serum albumin concentration at or near normal by means of intravenous albumin administration. These observations place on a firmer ground the use of a low sodium diet to reduce the rate of ascites accumulation (19). Such a diet must be prepared with care so that it will furnish an ample supply of calories, protein, and vitamins, and, at the same time be palatable. The preparation and use of such a diet are published elsewhere (20).

A satisfactory explanation of the failure to excrete administered sodium is not at hand. Ralli and her co-workers (3) demonstrated an antidiuretic effect similar to that of pituitrin in the urine of patients with cirrhosis and ascites. How- ever, retention of sodium is not one of the primary effects of the posterior pituitary antidiuretic substance $(21,22)$. The observations reported here suggest that sodium excretion is primarily at fault and therefore point rather to the antidiuretic effect of the sex hormones or of those elaborated by the adrenal cortex. It need not be postulated, however, that an antidiuretic is the sole or even most important cause of the failure of sodium excretion in cirrhosis. Other factors such as altered renal blood flow and glomerular filtration are being studied (16). At present too little data are available to draw definite conclusions in this regard.

The results reported here do not precisely define the relative importance in the formation of ascites, of the serum albumin concentration, the portal hypertension, or the failure to excrete administered sodium. Each is undoubtedly important, although recent studies tend to minimize the importance of the serum colloid osmotic pressure $(3,23)$.

\section{SUMMARY}

1. The patients with cirrhosis of the liver with ascites reported in this communication excreted only small quantities of sodium in the urine regardless of either the quantity of salt administered, or the route of its administration (oral and intravenous). The failure to excrete sodium in amounts adequate to achieve sodium equilibrium occurred in spite of the maintenance of a normal serum albumin concentration by repeated injections of concentrated salt-poor human serum albumin.

2. The urinary excretion of sodium was usually increased by the administration of mercurial diuretics or of salt-poor human serum albumin (intravenously) and also during a spontaneous decrease in ascites and edema formation.

3. A low sodium but otherwise adequate diet decreased the rate of ascites formation, while larger quantities of administered sodium led to a proportionately increased rate of formation.

4. Although several factors might have led to the failure of these patients to excrete sodium, there was no evidence that any one was solely implicated.

5. The relative importance of the failure to excrete sodium, of hypoalbuminemia, and of portal 
hypertension in the genesis of ascites could not be precisely defined.

\section{ACKNOWLEDGMENTS}

The authors wish to express their gratitude to Alice N. Ballou, Ellen V. Cobino, Catherine M. Murphy, and Ellen Doyle for technical assistance, and to Kathleen A. Clinton for preparation of the diets used in this study.

Since submitting this paper for publication, Farnsworth and Krakusin (Farnsworth, E. B., and Krakusin, J. S., Electrolyte partition in patients with edema of various origins. Qualitative and quantitative definition of cations and anions in hepatic cirrhosis, J. Lab. \& Clin. Med., 1948, 33, 1545) have likewise demonstrated a failure in patients with cirrhosis of the liver to excrete administered sodium in the urine.

\section{BIBLIOGRAPHY}

1. Post, J., and Patek, A. J., Jr., Serum proteins in cirrhosis of the liver. I. Relation to prognosis and to formation of ascites. II. Nitrogen balance on five patients. Arch. Int. Med., 1942, 69, 67 and 83.

2. Blakemore, A. H., Portocaval anastomosis: A report on fourteen cases. Bull. New York Acad. Med., 1946, 22, 254.

3. Ralli, E. P., Robson, J. S., Clarke, D., and Hoagland, C. L., Factors influencing ascites in patients with cirrhosis of the liver, J. Clin. Invest., 1945, 24, 316.

4. Janeway, C. A., Gibson, S. T., Woodruff, L. M., Heyl, J. T., Bailey, O. T., and Newhouser, L. R., Chemical, clinical, and immunological studies on the products of human plasma fractionation. VII. Concentrated human serum albumin. J. Clin. Invest., 1944, 23, 465.

5. Thorn, G. W., Armstrong, S. H., Jr., and Davenport, V. D., Chemical, clinical and immunological studies on the products of human plasma fractionation. XXXI. The use of salt-poor concentrated human serum albumin solution in the treatment of hepatic cirrhosis. J. Clin. Invest., 1946, 25, 304.

6. Kunkel, H. G., Labby, D. H., Ahrens, E. H., Jr., Shank, R. E., and Hoagland, C. L., The use of concentrated human serum albumin in the treatment of cirrhosis of the liver. J. Clin. Invest., 1948, $27,305$.

7. Faloon, W. W., Eckhardt, R. D., Murphy, T. L., Cooper, A. M., and Davidson, C. S., An evaluation of human serum albumin in the treatment of cirrhosis of the liver. J. Clin. Invest., 1949, 28, 583.

8. Layne, J. A., and Schemm, F. R., The use of a high fluid intake and a low-sodium, acid-ash diet in the management of portal cirrhosis. Gastroenterology, 1947, 9, 705.

9. Patek, A. J., Jr., and Post, J., Treatment of cirrhosis of the liver by a nutritious diet and supplements rich in vitamin B complex. J. Clin. Invest., 1941, 20, 481.

10. Wolf, A. V., and Lester, D. E., Personal communication.

11. Consolazio, W. V., and Dill, D. B., The determination of sodium. J. Biol. Chem., 1941, 137, 587.

12. Freyberg, R. H., and Grant, R. L., Loss of minerals through the skin when sweating is avoided. J. Clin. Invest., 1937, 16, 729.

13. Keutmann, E. H., Bassett, S. H., and Warren, S. L., Electrolyte balances during artificial fever with special reference to loss through skin. J. Clin. Invest., 1939, 18, 239.

14. Mackay, E. M., and Butler, A. M., Studies of sodium and potassium metabolism. The effect of potassium on the sodium and water balances in normal subjects and patients with Bright's disease. J. Clin. Invest., 1935, 14, 923.

15. Howe, P. E., The use of sodium sulfate as the globulin precipitant in the determination of proteins in the blood. J. Biol. Chem., 1921, 49, 93.

16. Patek, A. J., Jr., Mankin, H., Colcher, H., Lowell, A., and Earle, D. P., Jr., The effects of intravenous injection of concentrated human serum albumin upon blood plasma, ascites, and renal functions in three patients with cirrhosis of the liver. J. Clin. Invest., 1948, 27, 135.

17. Hickey, R. C., and Hare, K., The renal excretion of chloride and water in diabetes insipidus. J. Clin. Invest., 1944, 23, 768.

18. Goodman, L., and Gilman, A., The Pharmacological Basis of Therapeutics. A Textbook of Pharmacology, Toxicology and Therapeutics for Physicians and Medical Students. The Macmillan Company, New York, 1941, Ed. 1, p. 628.

19. Jones, C. M., and Volweiler, W., Therapeutic considerations in subacute and chronic hepatitis. Med. Clin. No. Amer., 1947, 31, 1059.

20. Chalmers, T. C., and Davidson, C. S., A survey of recent therapeutic measures in cirrhosis of the liver. New England J. Med., 1949, $240,449$.

21. Smith, F. M., and Mackay, E. M., Influence of posterior pituitary extracts on sodium balance in normal subject and in patient with diabetes insipidus. Proc. Soc. Exper. Biol. \& Med., 1936, 34, 116.

22. Ham, G. C., and Landis, E. M., A comparison of pituitrin with the antidiuretic substance found in human urine and placenta. J. Clin. Invest., 1942, 21, 455.

23. Mankin, H., and Lowell, A., Osmotic factors influencing the formation of ascites in patients with cirrhosis of the liver. J. Clin. Invest., 1948, 27, 145. 